\title{
Layanan bimbingan dan konseling terhadap anak terlantar di rehabilitasi sosial UPTD PSBS Dinas Sosial Provinsi Kepulauan Bangka Belitung
}

\section{Nurviyanti Cholid $^{1}$ | Yulinda ${ }^{2}$}

${ }^{1}$ Dosen Prodi Bimbingan dan Konseling Islam IAIN SAS

BABEL

${ }^{2}$ Mahasiswa Bimbingan dan Konseling Islam IAIN SAS BABEL

Korespondensi

vivihafizh@gmail.com

\begin{abstract}
Guidance and Counseling Services for Abandoned Children and Abandoned Persons/Elderly in Social Rehabilitation UPTD PSBS Social Service of the Archipelago Province. This research is a descriptive qualitative research that aims to find out how the guidance and counseling services provided to neglected children and the elderly in social rehabilitation UPTD PSBS Social Service of the Bangka Belitung Islands Province. The data sources used are primary data, namely the Head of the Social Apocacy Program, the Head of Subdivision of $\mathrm{TU}$, and the Head of Guidance and the secondary data are books, journals, theses, archives, and official documents at the Office of Social Institutions for Bina Serumpun Province of the Bangka Belitung Islands Province. Collecting data using the method of observation, interviews and documentation. The results showed that: Guidance and counseling services for abandoned children and abandoned people in the UPTD PSBS of the Archipelago Province Social Service can be classified into eight stages, namely the first stage: Initial Approach, second stage: acceptance, third stage: care, fourth stage: maintenance, and Social Protection Care, Fifth Stage: Assessment Stage, Sixth Stage: Coaching Stage, Seventh Stage: Distribution Stage, Eighth Stage: Termination Stage.

\section{KEYWORDS:}

Guidance and Counseling, Abandoned Children, Abandoned Parents, Social Rehabilitation.
\end{abstract}




\begin{abstract}
Abstrak
Layanan Bimbingan dan Konseling Terhadap Anak Terlantar dan Orang Terlantar/Lansia di Rehabilitasi Sosial UPTD PSBS Dinas Sosial Provinsi Kepulauan. Penelitian ini merupakan penelitian kualitatif deskriptif yang bertujuan untuk mengetahui bagaimana layanan Bimbingan dan konseling yang diberikan kepada Anak Terlantar dan Orang Terlantar/Lansia di rehabilitasi sosial UPTD PSBS Dinas Sosial Provinsi Kepulauan Bangka Belitung. Sumber data yang digunakan adalah data primer yakni Kasi Prog Apokasi Sosial, Kasubbag TU, dan Kasi Bimbingan dan Data sekundernya adalah buku, jurnal, skripsi, arsip, dan dokumen resmi yang ada di Dinas Panti Sosial Bina Serumpun Provinsi Kepulauan Bangka Belitung. Pengumpulan data menggunakan metode observasi, wawancara dan dokumentasi. Hasil penelitian menunjukkan : Pelayanan Bimbingan dan konseling Terhadap Anak Terlantar dan Orang Terlantar/Lansia di UPTD PSBS Dinas Sosial Provinsi Kepulauan dapat digolongkan menjadi delapan tahap yakni Tahap pertama : Pendekatan Awal, Tahap kedua: Penerimaan, Tahap ketiga: Perawatan, Tahap ke empat: Pemeliharaan, serta Asuhan Perlindungan Sosial, Tahap kelima: Tahap Assessment, Tahap ke enam: Tahap Pemberian Pembinaan, Tahap ke tujuh: Tahap Penyaluran, Tahap kedelapan : Tahap Terminasi.

\section{KATA KUNCI:}

Bimbingan dan Konseling, Anak terlantar, Orang Tua terlantar, Rehabilitasi Sosial.
\end{abstract}




\section{1 | Pendahuluan}

Pembangunan kesejahteraan sosial dengan pembangunan nasional merupakan suatu bagian yang tidak dapat dipisahkan dan telah berperan aktif dalam meningkatkan kualitas hidup demi terwujudnya kehidupan dan penghidupan yang bermartabat. Agar terwujudnya kondisi tersebut pembangunan bidang kesejahteraan sosial diselenggarakan melalui pelayanan dan pengembangan kesejahteraan sosial secara terprogram, terpadu, dan berkelanjutan sebagaimana diatur dalam Undang-Undang RI Nomor 11 Tahun 2009 tentang “Kesejahteraan Sosial”.

Pemerintah memiliki kedudukan dan peran aktif dalam peningkatan kesejahteraan dan keadilan masyarakat. Melalui Undang-Undang Nomor 32 Tahun 2004 Tentang Pemerintahan Daerah (PEMDA) yang kemudian direvisi dengan Undang-Undang Nomor 12 Tahun 2008, di setiap daerah diberikan kewenangan untuk dapat mengatur dan mengurus sendiri urusan pemerintahan yang diarahkan untuk mempercepat terwujudnya kesejahteraan masyarakat melalui peningkatan pelayanan, pemberdayaan dan pembangunan masyarakat, termasuk upaya pemerintah untuk menanggulangi masalah sosial, seperti orang terlantar dan anak terlantar.

$$
\text { Pasal } 34 \text { ayat } 5 \text { tentang }
$$
perekonomian nasional dan kesejahteraan sosial menjelaskan bahwa fakir miskin dan anak terlantar dipelihara oleh Negara. Fakir miskin dan anak terlantar semakin marak terutama daerah perkotaan, bahkan pada trafick light masih banyak para pengemis yang meminta belas kasihan kepada para pengemudi sepeda motor serta orangorang yang menghampirinya. Padahal seharusnya anak-anak terlantar di usia tersebut harus dapat mengenyam pendidikan formal [1].

Keberadaan orang terlantar (lansia) dan anak terlantar adalah salah satu masalah sosial yang banyak terjadi di Indonesia dan belum mampu ditangani secara maksimal terutama pada masalah sosial seperti kemiskinan dan ketelantaran. Masalah ini harus menjadi perhatian lebih dari pemerintah, karena masalah tersebut sudah menjadi bagian dari kehidupan masyarakat.

Kaum pengemis gelandangan dan orang terlantar (PGOT) dan anak 


\section{Ounselle}

Reviewed : 30-Oct-2021 | Accepted : 08-Dec-2021 | Published : 31-Dec-2021

terlantar dikategorikan sebagai bagian dari masyarakat perkotaan pada lapisan bawah, masyarakat miskin atau golongan have not sering disebut masyarakat marginal, terkadang terpinggirkan dan tidak luput dari perhatian pemerintah [2].

Dinas Sosial Provinsi Kepulauan Bangka Belitung merupakan tempat pelayanan dan rehabilitasi sosial, di mana sasaran layanan klien UPTD Panti Sosial Bina Serumpun Kepulauan Bangka Belitung adalah anak terlantar (ANTAR), anak yang berhadapan dengan hukum $(\mathrm{ABH})$, dan orang terlantar/lansia. Namun terdapat kriteria penerima manfaat dalam pelayanan rehabilitasi sosial terkhusus pada anak terlantar dan orang terlantar/lansia.

Kriteria tersebut antara lain: anakanak umur 12 tahun sampai dengan 18 tahun, lansia 60 tahun keatas, sehat jasmani dan rohani, tidak menerima psikotik dan ekspsikotik, tidak menerima klien yang berpenyakit menular berbahaya dan parah seperti penyakit hepatitis, TBC, flu burung, HIV, AIDS, dan penyakit berbahaya dan menular lainnya, tidak menerima klien cacat berat (permanen) dan cacat ganda, surat keterangan kesehatan dari dokter, surat keterangan domisili dari kepala desa/kelurahan/LSM/orsos/LKS dan lembaga sosial lainnya, surat rekomendasi dari dinas sosial kabupaten/kota, surat perjanjian bagi klien yang direhabilitasi di UPTD PSBS dengan materai Rp. 6.000, pas photo warna ukuran 3x4 cm sebanyak 3 lembar, untuk anak terlantar (ANTAR) surat pengantar dari kepolisian, kejaksaan, pengadilan, BAPAS, advokad (pengacara) dan LP, tidak menerima klien hamil, bersedia menaati peraturan dan tata tertib yang berlaku, mampu dididik dan dilatih, untuk orang terlantar/lansia tidak menerima yang mengalami sakit parah dan lumpuh total.

Tahapan dalam proses pelayanan antara lain: pendekatan awal, penerimaan, perawatan dan pemeliharaan, asesmen, pemberian pembinaan, resosialisasi, dan pembinaan lanjut. Selama dalam proses rehabilitasi sosial penerima manfaat mendapatkan pelayanan kebutuhan dasar dan berbagai keterampilan sesuai minat dan bakat yang dimiliki [3]. 


\section{2 | Metode}

\subsection{Jenis penelitian}

Adapun jenis penelitian yang digunakan peneliti adalah jenis penelitian lapangan (field research) dengan metode penelitian kualitatif deskriptif [4]. Kualitatif deskriptif merupakan prosedur penelitian yang menghasilkan data deskriptif berupa kata-kata tertulis atau lisan orang-orang dan perilaku yang dapat diamati.

\section{2 | Sumber Data}

Data merupakan bahan keterangan suatu objek penelitian yang diperoleh melalui penelitian [5]. Adapun sumber data yang berhubungan dengan penelitian ini adalah data primer dan sekunder. Sumber data primer dalam penelitian ini adalah orang yang menjadi sumber utama dalam penelitian ini yakni Kasi Prog Apokasi Sosial, Kasubbag TU, dan Kasi Bimbingan. Data Sekunder. Sumber data sekunder dalam penelitian ini, yang dijadikan sumber penunjang adalah buku, jurnal, skripsi, arsip, dan dokumen resmi yang ada di Dinas Panti Sosial Bina Serumpun Provinsi Kepulauan Bangka Belitung.

\section{2 | Teknik Pengumpulan Data}

Untuk mendapatkan data penelitian, maka peneliti menggunakan penelitian teknik pengumpulan data sebagai berikut:

a. Wawancara.

Wawancara merupakan bentuk komunikasi antara dua orang, melibatkan seseorang yang ingin memperoleh informasi dari seseorang lainnya dengan mengajukan pertanyaan-pertanyaan tertentu yang ada kaitannya dengan penelitian [6]. Dalam penelitian ini, peneliti menggunakan jenis wawancara tak terstrukur. Dalam tahapan wawancara ini, peneliti melakukan wawancara dengan beberapa pengurus dan pihak-pihak yang terlibat dalam pelayanan rehabilitasi sosial terhadap orang terlantar dan anak terlantar di UPTD Panti Sosial Bina Serumpun Dinas Sosial Provinsi Kepulauan Bangka Belitung.

b. Observasi

Observasi merupakan metode pengumpulan data dimana peneliti mencatat informasi sebagaimana yang disaksikan selama melakukan penelitian. Observasi yang digunakan dalam penelitian ini menggunakan observasi 


\section{Ounselle}

Reviewed : 30-Oct-2021 | Accepted : 08-Dec-2021 | Published : 31-Dec-2021

tidak terstruktur. Metode ini digunakan untuk mengamati langsung kegiatan pelayanan rehabilitasi sosial yang diberikan oleh UPTD Panti Sosial Bina Serumpun Dinas Sosial Provinsi Kepulauan Bangka Belitung dalam menangani orang terlantar dan anak terlantar.

c. Dokumentasi

Metode dokumentasi digunakan untuk mengetahui struktur organisasi dan hal-hal yang berhubungan dengan penelitian khususnya UPTD Panti Sosial Bina Serumpun Dinas Sosial Provinsi Kepulauan Bangka Belitung selain itu referensi dan buku-buku mengenai pelayanan dan rehabilitasi sosial yang berkaitan dengan penelitian penulis.

\section{3 | Teori}

\subsection{Pelayanan Bimbingan dan}

\section{Konseling}

Pelayanan merupakan pertolongan dalam menyediakan segala sesuatu yang diperlukan oleh orang lain. Pelayanan dapat diberikan kepada orang lain sebagai pertolongan yang dibutuhkan orang lain. Dengan pertolongan tersebut dapat membantu orang lain dalam mengatasi permasalahan yang dialami
[7]. Pelayanan sosial sendiri suatu usaha kesejahteraan sosial yang diberikan kepada anak terlantar ataupun orang terlantar yang telah ditetapkan sebagai penerima manfaat dalam bentuk penyelenggaraan penyantunan, perawatan, pengembangan kapasitas, penyaluran, dan penempatan sesuai dengan hasil asessment.

Bimbingan adalah proses pemberian bantuan kepada individu untuk mencapai pemahaman diri agar dapat menyesuaikan diri dengan lingkungan dan keadaan. Namun jika layanan bimbingan dilakukan di sekolah, bimbingan dapat diartikan sebuah proses berupa bantuan yang diberikan oleh guru pembimbimbing kepada siswa agar dapat melewati setiap tahap perkembangannya.

Adapun konseling adalah proses bantuan yang diberikan seorang ahli kepada individu secara sistematis dengan menggunakan pendekatan tertentu dalam mengentaskan atau mengatasi masalah individu [8]. Jadi bimbingan dan konseling adalah sebuah layanan yang diberikan seorang ahli berupa bantuan dalam upaya mengembangkan diri individu dan memecahkan masalah yang 
dihadapi individu secara sistematis dan bertahap.

\section{2 | Rehabilitasi Sosial}

Menurut Kamus Besar Bahasa Indonesia $(\mathrm{KBBI})$ rehabilitasi adalah proses pemulihan kedudukan (nama baik) yang awalnya memperbaiki anggota tubuh yang cacat atau yang lainnya (misalnya pasien rumah sakit, korban kecelakaan) untuk menjadikan manusia yang berguna dan sesuai dengan posisi dimasyarakat [9].

Juga dapat dikatakan bahwa rehabilitasi merupakan usaha dalam memperbaiki penderita cacat baik secara fisik ataupun psikis, demi mewujudkan seoptimal mungkin kegunaan ekonomi, rohani, jasmani, pekerjaan, dan sosial. Sehingga dapat berfungsi lagi sebagai anggota masyarakat yang berguna bagi diri sendiri maupun di masyarakat itu sendiri.

Rehabilitasi sosial sebagaimana dimaksud dalam ayat 2 mengenai bentuk pemberian berupa: motivasi dan diagnosis psikososial, perawatan dan pengasuhan, pelatihan vokasional dan pembinaan kewirausahaan, bimbingan mental spiritual, bimbingan fisik, bimbingan sosial dan konseling psikososial, pelayanan aksesibilitas, bantuan dan asistensi sosial, bimbingan resosialisasi, bimbingan lanjut dan rujukan.

Rehabilitasi sosial (social rehabilitation) juga suatu bagian dari proses rehabilitasi penderita cacat yang berusaha untuk menghilangkan atau usaha mengurangi semaksimal mungkin pengaruh-pengaruh negatif yang diakibatkan oleh kecacatannya sehingga dapat lebih aktif untuk menjalani kehidupan bermasyarakat. Dengan upaya pelayanan rehabilitasi sosial yang diberikan oleh tenaga kepada penderita merupakan serangkaian kegiatan untuk mengembalikan bekas penderita ke dalam masyarakat sehingga dapat berfungsi lagi sebagai anggota masyarakat yang berguna untuk dirinya dan masyarakat semaksimal mungkin sesuai dengan kemampuannya [10].

\section{3 | Anak-anak terlantar}

Anak-anak terlantar adalah suatu kelompok anggota masyarakat yang kurang beruntung karena berbagai faktor yang dialami pada keluarganya, seperti masalah ekonomi. Menurut Direktorat Pelayanan Sosial Anak Depsos RI, 


\section{Ounselle}

Reviewed : 30-Oct-2021 | Accepted : 08-Dec-2021 | Published : 31-Dec-2021

mengatakan bahwa anak-anak terlantar di jalanan atau disebut dengan children of the street adalah anak-anak yang hanya memanfaatkan hampir seluruh waktunya di jalanan. Karena anak-anak jalanan ini mengalami kerenggangan bahkan terputusnya hubungan dengan orangtuanya, sehingga mereka harus tinggal disuatu tempat yang rentan sering terjadi pelecehan sosial, fisik, emosional, dan bahkan pelecehan seksual.

Pada usia anak-anak mereka seharusnya diberikan berbagai kewajibannya sebagai anak, seperti pemberian hak belajar, bermain dan perhatian dari orang-orang sekitarnya. Namun, berbeda dengan mereka yang harus menghabiskan masa kecil di jalanan dengan keadaan yang sangat memprihatinkan. Hal ini menjadi pusat perhatian bagi pemerintah untuk menanggulangi permasalahan tersebut. Ciri-ciri anak terlantar diantaranya :

a) Mereka yang berusia 5 tahun sampai 18 tahun yang merupakan anak yatim, piatu, atau yatim piatu.

b) Melakukan aktivitas atau sering berkeliaran di jalanan. c) Penampilannya kebanyakan kotor dan kusam.

d) Pakaian yang tidak terurus.

e) Mobilitasnya tinggi.

f) Tidak memiliki tempat tinggal.

g) Jauh dari keluarga.

h) Anak yang lahir dati hubungan seks atau diluar nikah yang kemudian dibuang.

Faktor-faktor adanya anak terlantar;

a) Kemiskinan;

b) Kebodohan;

c) Urbanisasi;

d) Ketiadaanlapangan pekerjaan;

e) sulitnya mendapatkan pelayanan pendidikan, kesehatan dan sebagainya.

Namun, hidup dijalanan bukanlah pilihan yang menyenangkan, karena mereka dalam kondisi yang tidak bermasa depan jelas, dan keberadaan mereka tidak jarang menjadi masalah bagi berbagai pihak keluarga, masyarakat dan Negara. Dengan masalah tersebut, kita sebagai saudara mereka justru harus lebih sigap dalam memberikan bantuan kepada mereka. Dengan demikian, pelayanan rehabilitasi sosial yang diselenggarakan oleh pemerintah berperan penting dalam 
mengurangi ketelantaran anak-anak yang saat ini tidak jarang terjadi. Dan bahkan harus lebih maksimal mungkin dalam menanggulangi proses pelayanan rehabilitasi pada anak-anak terlantar.

Jenis-jenis rehabilitasi:

a. Rehabilitasi Medis (Medical Rehabilitation)

Rehabilitasi medis adalah kegiatan spesialisasi ilmu kedokteran yang berhubungan dengan penanganan secara menyeluruh (comprensive management) dari pasien yang mengalami gangguan fungsi/cedera (impairment), (musculoskeletal), susunan otot saraf (sistem) serta gangguan mental, sosial dan yang menyertai kecacatan tersebut.

Ruang lingkup kegiatan rehabilitasi sosial:

- Pemeriksaan fisik.

- Mengadakan diagnosa.

- Pengobatan dan pencegahan.

- Latihan dan penggunaan alat-alat bantu dan fungsi fisik.

Terdapat beberapa tujuan dalam rehabilitasi medis, seperti:

- Jangka pendek, yaitu pasien dapat segera keluar dari tempat tidur dan bisa berjalan tanpa alat bantu, paling tidak dapat memelihara diri sendiri.

- Jangka panjang, yaitu pasien dapat hidup kembali di masyarakat, bisa menjaga diri sendiri, dan dapat kembali menjalani kegiatan seperti biasanya, paling tidak mendekatinya.

b. Rehabilitasi Karya (Vocational

\section{Rehabilitation)}

Istilah rehabilitasi vokasional berarti bagian dari suatu psoses rehabilitasi secara berkesinambungan dan terkoordinasikan yang menyangkut pengadaan pelayanan-pelayanan di bidang jabatan, seperti bimbingan jabatan, latihan kerja dan penempatan yang selektif dengan diadakannya pelayanan ini memungkinkan para penderita cacat lebih memperoleh kepastian dan mendapatkan pekerjaan yang layak.

Adapun kegiatan dalam rehabilitasi ini sebagai berikut:

- Kegiatan evaluasi.

- Bimbingan vokasional.

- Latihan kerja.

- Penempatan kerja dan follow up. 


\section{Ounselle}

Reviewed : 30-Oct-2021 | Accepted : 08-Dec-2021 | Published : 31-Dec-2021

c. Rehabilitasi Sosial

Merupakan bagian dari proses rehabilitasi penderita cacat yang berusaha untuk menghilangkan atau setidaknya mengurangi semaksimal mungkin pengaruh negatif yang diakibatkan oleh kecacatannya, sehingga penderita dapat kembali melakukan aktivitas seperti biasanya di masyarakat, paling tidak mengikuti.

d. Rehabilitasi Psikologis

Rehabilitasi psikologis adalah bagian dari proses rehabilitasi penderita cacat yang berusaha untuk menghilangkan atau setidaktidaknya mengurangi semaksimal mungkin pengaruh negatif yang disebabkan oleh kecacatan terhadap mental penderita cacat serta melatih mempersiapkan mental mereka agar siap dan mampu menyesuaikan diri di masyarakat.

\section{4 | Hasil dan Pembahasan}

Dari hasil penelitian, penulis menemukan beberapa tahapan dalam proses bimbingan dan konseling yang diberikan kepada anak terlantar di rehabilitasi sosial UPTD Panti Sosial Bina
Serumpun Provinsi Kepulauan Bangka Belitung :

1) Tahap Pendekatan Awal Pendekatan awal merupakan proses kegiatan yang mengawali keseluruhan proses layanan Bimbingan dan Konseling yang ada di Panti Sosial Bina Serumpun Pronvinsi Kepulauan Bangka Belitung. Adapun tahap dalam pendekatan awal, seperti penjangkauan, observasi, identifikasi, motivasi dan seleksi. langkahlangkah tersebut yaitu :

a. Penjangkauan

Penjangkauan yang ada di panti ini suatu proses memperkenalkan atau pemberitahuan sesuatu yang berkaitan tentang bimbingan dan konseling yang akan diberikan oleh pihak panti di panti tersebut.

b. Observasi

Observasi ini berupa pengamatan yang dilakukan oleh pihak panti dengan tujuan mencari informasi secara jelas terkait klien dan permasalahannya. Seperti mencari tahu tempat tinggal klien, keluarga klien dan permasalahan dari klien. 
c. Identifikasi

Identifikasi adalah proses pengumpulan data dan informasi awal sebelum dilakukannya assessment. Metode yang digunakan berupa wawancara yang menanyakan seputaran keluarga, kegiatan yang dilakukan seharihari, dan kemauan untuk masuk di panti ini serta persyaratan-persyaratan yang harus dipenuhi. Hal senada yang diungkapkan oleh bapak Albian Aid:

"Ketika peksos Kabupaten/Kota mengantarkan klien ke dinsos maka yang mengambil alih terhadap klien itu saya, selaku kasi rehabilitasi sosial, disitu saya perkenalan dulu dan mewawancarai klien terkait kehidupannya untuk dapat mengetahui informasi klien." (Albian , 2020)

\section{d. Motivasi}

Motivasi berupa pengenalan program kepada klien untuk menumbuhkan keinginan dan mendorong guna dapat melaksanakan program di panti sosial. Seperti yang dikatakan bapak Albian:

"Klien orang terlantar dan anak terlantar ketika datang ke sini saya berikan motivasi dahulu, bahwa disini itu sangat baik, tinggal di panti ini aman dan jangan takut untuk tinggal disini karena banyak orangorang yang baik dan lebih peduli." e. Seleksi

Seleksi ini proses pengelompokkan penyandang masalah kesejahteraan sosial terutama yang sudah diberikan motivasi, untuk menentukan siapa yang memenuhi persyaratan dan tidak dapat diterima menjadi calon penerima pelayanan. Namun proses seleksi juga dilakukan dengan melihat kondisi calon penerima pelayanan, apakah hasil dari wawancara sama halnya dengan kondisi ia saat ini. Ini dikatakan bapak Albian:

"Lalu setelah semuanya selesai maka pihak panti melakukan rapat untuk menentukan klien ini layak atau tidak tinggal di panti ini, setelah dikatakan layak, langsung di ambil alih oleh bagian program dan advokasi sosial untuk dilakukan pendataan lanjutan."

2) Tahap Penerimaan

Tahap penerimaan adalah tahap kedua dari proses pelayanan bimbingan dan konseling. Tujuannya agar dapat mendapatkan informasi yang lebih lengkap mengenai kondisi klien yang dibutuhkan untuk mengembangkan suatu rencana intervensi yang akan dilakukan pada tahap selanjutnya. Pada tahap ini, jika penyandang masalah kesejahteraan sosial sudah dinyatakan sebagai calon penerima pelayanan, maka 


\section{Ounselle}

Reviewed : 30-Oct-2021 | Accepted : 08-Dec-2021 | Published : 31-Dec-2021

dilakukan proses registrasi, persyaratan administrasi, dan penempatan dalam panti.

Khusus untuk orang terlantar (lansia) dapat dikatakan mereka yang sudah berusia 60 tahun keatas dan tidak dapat lagi memenuhi kebutuhan hidupnya sendiri serta ditelantarkan oleh keluarganya, sedangkan untuk anak terlantar yang berusia 5-12 tahun yang berfaktor pada keluarga yang tidak baik dan tega menelantarkan anak-anak mereka. Setelah klien diterima di panti, maka dilakukan proses pemeriksaan kesehatan oleh perawat karena ditakutkan klien mengidap penyakit lainnya serta dilakukan pembersihan kepada klien orang terlantar (Iansia) dan anak terlantar oleh petugas panti. Dan klien langsung di bawa ke kamar asrama sesuai jenis kelaminnya.

\section{a. Registrasi}

Proses pendaftaran bagi calon penerima pelayanan secara langsung untuk dapat melanjutkan pada tahap selanjutnya.

b. Persyaratan administrasi

Pada proses ini, setelah dilakukan registrasi atau pendaftaran, maka penerima pelayanan wajib memenuhi persyaratan administrasi berupa data diri penerima pelayanan agar informasi dari klien lebih lengkap dan mudah diketahui masalah yang dihadapi.

c. Penempatan dalam panti

Untuk calon penerima pelayanan yang sudah dinyatakan memenuhi segala persyaratan, maka penerima pelayanan sudah dapat menempatkan dirinya di asrama panti dengan sesuai jenis kelaminnya dan selalu mentaati aturan yang berlaku. Seperti pernyataan kasi rehabilitasi sosial pak Albian:

"Ya, pada tahap ini jika klien sudah
memenuhi syarat maka dilakukan
berbagai macam regitrasi,
kelengkapan administrasi, dan
penempatan di asrama, yang mana
terlebih dahulu dilakukan
pemeriksaan kesehatan dan
kebersihan oleh perawat yang ada di
panti."

3) Tahap Intervensi

Setelah klien lansia dan anak terlantar menempati asrama yang sudah disediakan, maka klien tersebut langsung mendapatkan intervensi dari layanan bimbingan dan konseling di Panti Sosial Bina Serumpun oleh petugas berupa Perawatan, pemeliharaan dan asuhan perlindungan social. Tujuannya agar para klien lebih terurus, aman dan terlindungi dari segala masalah yang 
dihadapi. Seperti pernyataan dari bapak

Takdir selaku kasi program dan advokasi sosial:

“Klien yang sudah dinyatakan dapat menempati asrama, maka klien langsung dilakukan proses bimbingan dan konseling seperti perawatan, pemeliharaan dan asuhan perlindungan sosial yang ada di panti, hal ini tentu akan menjadikan klien lebih terurus dan terlindungi serta diberikan pelayanan terbaik sesuai tugas dan fungsi Panti Sosial Bina Serumpun Provinsi Kepulauan Bangka Belitung."

Di dalam intervensi dalam layanan bimbingan dan konseling ada beberapa proses atau tahapan yang diberikan oleh petugas panti diantaranya:

a. Tahap Assessment

Asessment adalah proses penelaahan, pengungkapan dan pemahaman serta menganalisis dan menilai mengenai permasalahan klien serta kondisi lingkungannya, kemudian menetukan langkah-langkah pemberian pelayanan yang sesuai. Hal ini diungkapkan oleh bapak Albian:

"Di tahap assessment ini saya lebih menggali informasi terkait klien, seperti kenapa kamu bisa seperti ini, apa yang telah terjadi, dan kenapa bisa berada di sini, apa masalahnya, terus saya menanyakan keluarganya ada dimana, setelah itu apa yang kamu suka dan apa yang kamu inginkan, hal ini saya tanyakan karena ingin mencari solusi dalam masalah klien agar tujuan yang diinginkan segera terwujudkan."

b. Tahap Intervensi

Adapun intervensi yang diberikan pihak panti kepada klien Panti Sosial Bina Serumpun, seperti bimbingan fisik, kesehatan, mental, spiritual, sosial, dan keterampilan-keterampilan kerja usaha kemandirian, yang meliputi : pertanian, peternakan, dan perikanan.

1) Bimbingan Fisik

Pemberian bimbingan fisik yang ada di Panti Sosial Bina Serumpun Provinsi Bangka Belitung berupa senam pagi dan olahraga yang dilakukan setiap waktu pagi. Para klien orang terlantar dan anak terlantar selalu di bangunkan di pagi hari untuk melakukan aktivitas olahraga pagi agar tetap menjaga kesehatan jasmani klien.

\section{2) Bimbingan Kesehatan}

Para petugas memberikan pelayanan kesehatan, seperti memberikan obat sesuai anjuran perawat/dokter, pengecekan tensi, gula darah, asam urat, kolesterol, berat badan, dan tinggi badan terhadap klien yang dilakukan secara rutin supaya kesehatan klien tetap 


\section{Ounselle}

Reviewed : 30-Oct-2021 | Accepted : 08-Dec-2021 | Published : 31-Dec-2021

e-ISSN 2798-4230

DOI: $10.32923 /$ couns.v1i2.1806

p-ISSN XXXX-XXXX

Vol. 1, No. 2, Dec (2021)

terjamin. Hal senada yang dikatakan oleh

bapak Albian:

"Klien yang di bawa ke panti ini, mereka sudah mendapatkan tanggungan untuk berobat, seperti BPJS, BPJS ni yang ngurus para pekerja sosial yang mengantar mereka ke panti, jadi klien khusus yang orang terlantar (lansia) sudah terjamin untuk berobat jika mereka mengalami sakit."

\section{3) Konseling Spiritual (keagamaan)}

Konseling keagamaan ini diberikan oleh konselor atau penyuluh honor yang dari luar panti atau penyuluh tidak tetap kepada klien terutama anak terlantar dan orang terlantar/lansia. Pendekatan yang diberikan konselor dalam layanan konseling di panti ini seperti wudhu, sholat, puasa, mengaji dan lain-lain. Intervensi ini dilakukan 1 kali dalam 1 minggu. Hal ini bertujuan agar dapat menjadikan klien Panti Sosial Bina Serumpun untuk lebih memahami pentingnya melaksanakan ibadah agar dapat memiliki rasa kebermaknaan dalam diri walau apapun takdir yang sedang mereka jalani. Hal ini diungkapkan oleh bapak Pratikto Wiratama selaku pekerja sosial UPTD Panti Sosial Bina Serumpun:

"Saya lihat klien disini juga diberikan konseling spiritual atau keagamaan, mereka diajarkan mengaji, sholat setiap waktunya agar hati mereka tenang dan hidup mereka lebih bermakna, alhamduillah kegiatan ini selalu dilakukan klien di panti ini terkhusus lansia terlantar dan anak terlantar."

4) Bimbingan dan konseling Sosial Layanan Bimbingan maupun konseling bidang sosial yang diberikan konselor di Panti Sosial Bina Serumpun berupa bimbingan individu, bimbingan kelompok, konseling kelompok, dan rekreasi atau hiburan. Tujuan dari bimbingan dan konseling sosial adalah untuk menumbuhkan rasa jiwa sosial yang sebelumnya hilang, yang mana, rasa ketakutan dan keminderan kepada orang lain lebih mendominasi. Hal ini juga membantu para klien lebih mudah bergaul dan bersosial jadi lebih baik lagi. Ini diungkapkan oleh bapak Abang Evan Savitri selaku ketua Panti:

\begin{abstract}
"Jadi, yang memberikan bimbingan dan konseling sosial ini biasanya para penyuluh honor yang dari luar, ini sering dilakukan satu bulan 2 kali, atau seminggu 1 kali dalam memberikan bimbingan dan konseling kepada orang terlantar (lansia) dan anak terlantar, pemberian bimbingan dan konseling ini sangat saya apresiasikan karena hal ini positif dilakukan untuk membantu pikiran para klien."
\end{abstract}

5) Bimbingan Pendidikan

Bimbingan pendidikan yang ada di PSBS berupa pendidikan nonformal 
(paket A, B, dan C), serta bimbingan belajar. Hal ini dilakukan agar klien yang putus sekolah dapat kembali belajar dan bisa menjalani dunia pendidikan. Seperti yang diungkapkan bapak Albian mengatakan:

"Untuk bimbingan pendidikan ini hanya khusus pada anak terlantar tidak untuk lansia terlantar, dalam proses pembelajaran pun tidak jauh dari sekolah biasanya, mereka (klien) sama mendapatkan pelajaran yang baik sesuai pendidikan biasanya, yang membedakannya mereka sekolah yang namanya paket $A, B$, dan $C$, anak-anak terlantar ini di ajarkan oleh petugas disini namanya pak rahmat dan pak buin untuk ngambil paket $A, B$, dan $C$ tadi, anakanak terlantar ini juga diberikan perlengkapan sekolah, seperti alat tulis, seragam, sepatu, topi dan lainnya, mereka diperlakukan hampir sama dengan anak yang sekolah seperti biasanya, tujuannya ini supaya anak-anak yang kurang beruntung ini tetap merasakan sekolah."

6) Bimbingan Keterampilan

Panti Sosial Bina Serumpun Provinsi Kepulauan Bangka Belitung menyediakan berbagai macam keterampilan kerja usaha yang diberikan kepada orang terlantar (lansia) dan anak terlantar, namun lebih berfokus pada lansia di panti tersebut, seperti peternakan, perikanan, dan pertanian dan juga keterampilan kerajinan, seperti menjahit, memanfaatkan barang-barang bekas untuk diolah kembali. Sedangkan untuk anak terlantar lebih kepada mengurus diri sendiri, pekerjaan rumah, seperti bersihbersih lingkungan sekitar, mencuci piring dan sebagainya.

Tujuan dari pemberian bimbingan keterampilan ini sejalan dengan tujuan umum dari proses bimbingan itu sendiri yakni mengupayakan agar individu dapat mengembangkan diri dan mengoptimalkan bakat yang ada pada diri individu. Hal senada yang diungkapkan oleh bapak Albian:

"Klien yang ada disini bukan hanya
sekedar tidur dan makan, tetapi
mereka juga diberikan bimbingan
keterampilan yang mungkin awalnya
mereka belum tau dan setelah
berada disini mereka menjadi tau, ini
juga salah satu tujuannya supaya
ketika klien pulang dari panti, mereka
sudah mendapatkan bekal ilmu yang
positif, dan alhamdulilahnya
bimbingan ini terlaksana dengan
cukup baik, saya pribadi sangat
senang ketika klien melaksanakan
berbagai macam keterampilan itu."
(Albian, 2020).

Dalam memberikan keterampilan kerja kepada klien, Panti Sosial Bina Serumpun Dinas Sosial Provinsi Kepulauan Bangka Belitung bekerja sama dengan Balai Latihan Kerja Industri (BLKI) Provinsi Kepulauan Bangka Belitung. 


\section{Ounselle}

Reviewed : 30-Oct-2021 | Accepted : 08-Dec-2021 | Published : 31-Dec-2021

e-ISSN 2798-4230

DOI: $10.32923 /$ couns.v1i2.1806

p-ISSN XXXX-XXXX

Vol. 1, No. 2, Dec (2021)

Untuk penempatan latihan kerja tersebut

juga sesuai dengan minat dan bakat para

klien. Ini diungkapkan oleh bapak Abang

Evan Savitri:

\begin{abstract}
"Memang benar bahwa keterampilan ini bukan hanya ada di panti, namun kita juga bekerja sama (MOU) dengan Instansi Balai Latihan Kerja Industri (BLKI) Provinsi Bangka Belitung untuk penetapan klien sesuai minat dan bakatnya, hal ini dilakukan juga bertujuan untuk menambah wawasan keterampilan para klien sesuai apa yang diinginkan mereka."
\end{abstract}

Adapun keterampilan kerja yang disiapkan oleh Balai Latihan Kerja Industri (BLKI) Provinsi Bangka Belitung, seperti keterampilan pengelasan SMAW 3G, desain grafis, teknik telpon seluler perangkat keras, teknik instalasi listrik, pemeliharaan kendaraan ringan sistem injeksi, pengoperasian mesin bubut, operator komputer, menjahit pakaiaan wanita dewasa, tata boga, dan konstruksi baja ringan. Hal ini bertujuan untuk meningkatkan keterampilan klien didunia kerja, supaya ketika klien sudah keluar dari lembaga Panti Sosial Bina Serumpun mereka sudah dibekali pengetahuan tentang pekerjaan sesuai minat dan bakatnya.

\section{c. Tahap Penyaluran}

Tahap penyaluran adalah suatu kegiatan yang mengarahkan klien hidup secara normal di dalam lingkungan masyarakat, baik itu lingkungan keluarga ataupun lingkungan tempat tinggalnya. Toha, Proses ini dilakukan oleh pekerja sosial atau staff panti yang di tugaskan oleh Kepala Panti Sosial Bina Sosial Provinsi Kepulauan Bangka Belitung untuk penyaluran ke tempat asal apabila ditemukan keluarganya, dan apabila batas waktu yang ditentukan keluarga klien belum ditemukan, maka akan dilakukan perpanjangan waktu klien untuk tetap berada di Panti Sosial Bina Serumpun Provinsi Kepulauan Bangka Belitung sampai ditemukan keluarganya. Sebelum orang terlantar (lansia) dan anak terlantar di pulangkan ke tempat asal mereka sudah dibekali rasa percaya diri untuk dapat mudah bersosialisasi di lingkungan masyarakat tempat tinggalnya. Hal senada diungkapkan oleh pekerja sosial bapak Tikto:

"Jadi, sebelum klien ini dipulangkan ke tempat asalnya mereka terlebih dahulu sudah mendapat bekal percaya diri yang sudah saya berikan berupa motivasi agar mereka lebih berani untuk hidup bersosial dalam keluarga dan di lingkungan tempat tinggalnya." 
d) Tahap Bina Lanjut

Tahap bina lanjut merupakan tahap dimana upaya untuk memantapkan kemandirian mantan klien UPTD Panti Sosial Bina Serumpun Bangka Belitung yang telah di rujuk ke panti berikutnya atau ke rumah asalnya. Tujuannya untuk mengetahui kondisi para orang terlantar (lansia) dan anak terlantar setelah keluar dari Panti Sosial Bina Serumpun Bangka Belitung. Karena setelah mantan klien orang terlantar dan anak terlantar selesai mendapatkan pelayanan rehabilitasi sosial di Panti Sosial Bina Serumpun Provinsi Kepulauan Bangka Belitung mereka tentu tidak dilepas begitu saja oleh panti, akan tetapi mereka ada bimbingan lanjut yang diberikan oleh panti, seperti motivasi hidup mandiri dan menerapkan keterampilan yang mereka dapatkan dari pihak panti. Hal ini sesuai yang dikatakan oleh bapak Takdir Alamsyahbana:

"Para klien orang terlantar dan anak terlantar di sini ketika mereka sudah keluar dari panti ini, yang mana mereka sudah bertemu dengan keluarganya atau tinggal di panti berikutnya, mereka tetap diperhatikan perkembangannya, tetap di monitoring oleh pihak Panti Sosial Bina Serumpun seperti apa kondisinya, apakah ada perubahan pada mantan klien di PSBS ini sendiri, dan mereka tetap diberikan bimbingan motivasi, nasehat dan sebagainya."

Sebenarnya tahap bina lanjut ini juga suatu proses pemantauan yang dilakukan oleh pekerja sosial, dan tetap mencari informasi kondisi mantan klien saat sudah keluar dari panti tersebut, dan ini juga bertujuan memberikan informasi kepada mantan klien terkait mencari pekerjaan yang cocok. Namun, dikarenakan ini orang terlantar (lansia) yang mungkin sudah tidak diharuskan lagi bekerja keras karena kondisi, tetapi pekerja sosial memberikan pengetahuan lebih tentang keterampilan yang diberikan waktu di panti, sedangkan untuk anak terlantar dikarenakan masih usia sekolah maka, pekerja sosial hanya memberikan pendampingan secara lanjut ketika anak terlantar berada di panti selanjutnya atau sudah berada dikeluarganya. Pendapat ini juga disampaikan oleh bapak Yusandri:

"Memang betul para pekerja sosial mereka yang bertugas mencari informasi terkait kondisi dan kelanjutan pendampingan kepada mantan klien di PSBS, karena mantan orang terlantar (lansia) dan anak terlantar di PSBS ini tetap menjadi pantauan dari pihak panti mengenai kondisinya." 


\section{Ounselle}

Reviewed : 30-Oct-2021 | Accepted : 08-Dec-2021 | Published : 31-Dec-2021

\section{d. Tahap Terminasi}

Tahap ini merupakan tindakan atau kegiatan mengakhiri atau pemutusan secara resmi dalam proses rehabilitasi sosial.

Dalam hal ini apabila khusus anak terlantar telah menyelesaikan pendidikan paketnya. Terminasi juga dilakukan apabila keluarga klien sudah ingin mengambil klien untuk tinggal bersama mereka kembali. Hal ini sesuai yang diungkapkan oleh bapak Albian selaku Kasi Rehabilitasi Sosial:

"Jadi terminasi ini dapat terjadi jika keluarga klien ini sudah ingin membawa klien (orang terlantar dan anak terlantar) untuk pulang kerumah, maka proses terminasi berjalan."

Pada dasarnya harapan dari berbagai pihak panti mengharapkan untuk semua klien yang ada di PSBS ini dapat berkumpul lagi dengan keluarganya dan bisa bersosialisasi dengan baik di lingkungan sekitar tempat tinggalnya serta dapat berfungsi dengan baik sesuai sewajarnya. Karena lingkungan yang paling baik untuk semua orang adalah berada dekat dengan keluarga.

Segala kegiatan yang dilakukan pasti ada yang namanya penghambat dan pendukung, begitu juga dengan proses pelayanan rehabilitasi sosial. Terkhusus kepada UPTD Panti Sosial Bina Serumpun Provinsi Kepulauan Bangka Belitung mereka memiliki penghambat dan pendukung tersendiri dalam melaksanakan kegiatan pelayanan rehabilitasi sosial. Namun, tidak menjadi permasalahan bagi pihak panti untuk terus memberikan pelayanan yang terbaik kepada klien-klien yang ada di Panti Sosial Bina Serumpun Provinsi Kepulauan Bangka Belitung. Adapun Faktor penghambat dan faktor pendukung dalam proses pelayanan rehabilitasi sosial di UPTD PSBS Provinsi Kepulauan Bangka Belitung sebagai berikut:

\subsection{Fakor Penghambat}

Terdapat berbagai macam penghambat dalam proses pelayanan rehabilitasi sosial di UPTD PSBS Bangka Belitung, yaitu

a. Sikap klien yang kurang kerja sama dalam proses bimbingan, seperti masih keras kepala dan susah diatur, hal ini bisa jadi karena faktor bawaan waktu klien berada di lingkungan awalnya. Sehingga proses rehabilitasi sosial terkadang terjadi 
hambatan. Hal senada yang di sampaikan oleh bapak Albian:

\begin{abstract}
"Kami jika melihat klien yang susah untuk diatur, terkadang kami sangat sulit untuk mengarahkan klien untuk ikut proses bimbingan, makanya terkadang ada kendala sedikit ketika mengajak klien untuk melakukan proses bimbingan."
\end{abstract}

b. Masih kurangnya sumber daya manusia (SDM) yang saat ini menjadi pengaruh besar demi kelancaran proses pelayanan di panti. Karena masih kurangnya tenaga pengurus untuk membantu klien di panti dan juga kurangnya keilmuan yang dimiliki para petugas. Sehingga terkadang para tenaga lain sedikit kesusahan dalam mengatur proses pelayanan rehabilitasi sosial di Panti Sosial Bina Serumpun. Karena jika SDM yang tercukupi kemungkinan proses pelayanan mudah terkendali sehingga proses pelayanan rehabilitasi sosial di panti ini berjalan dengan sesuai harapan. Ini di ungkapkan oleh bapak Abang Evan Savitri selaku Kepala Panti:

"Di panti ini masih kekurangan SDM untuk membantu proses pelayanan, dan kami jika membutuhkan orang yang ahli dalam mengurus klien dari bidang memberikan bimbingan dan sebagainya itu kami ada petugas yang dari luar, maksudnya pegawai yang tidak tetap berada di panti ini, mereka termasuk pada penyuluh honor yang tetap di bayar, dan kami pun berharap petugas yang di panti harus sesuai dengan bidang keilmuan yang dimilikinya, seperti ada psikolognya, perawatnya, penyuluhnya dan harus lebih memahami bidang keilmuannya di panti serta professional"

\section{2 | Faktor pendukung}

Terkait dengan faktor pendukung, proses pelayanan rehabilitasi sosial di PSBS juga dapat berjalan karena adanya pendukung di dalamnya, bukan hanya sekedar hambatan yang dapat menjadikan kita untuk tidak melaksanakan kewajiban kita sebagai manusia untuk membantu antar sesama. Faktor pendukung ini seperti:

a. Sarana dan prasarana yang saat ini sudah cukup untuk mencukupi proses pelayanan rehabilitasi sosial di Panti Sosial Bina Serumpun Provinsi Kepulauan Bangka Belitung, seperti tersedianya akomodasi yang cukup untuk keperluan sehari-hari para klien terkhusus orang terlantar (lansia) dan anak terlantar. Begitu juga dengan tempat petugasnya yang sudah tersedia untuk melakukan berbagai macam bimbingan. Ini disampaikan oleh bapak Albian selaku Kasi Rehabilitasi Sosial di UPTD Panti Sosial Bina Serumpun. 


\section{Ounselle}

Reviewed : 30-Oct-2021 | Accepted : 08-Dec-2021 | Published : 31-Dec-2021

b. Kerja sama dengan Balai Latihan Kerja Industri (BLKI) Provinsi Kepulauan Bangka Belitung untuk memberikan keterampilan kepada klien di panti terkhusus pada orang terlantar (lansia). Klien tidak hanya mendapatkan keterampilan yang ada di dalam panti, namun juga diberikan kesempatan untuk memilih keterampilan sesuai minat dan bakat klien yang tersedia di BLKI Provinsi Kepulauan Bangka Belitung. Hal senada yang diungkapkan oleh bapak Takdir Alamsyahbana selaku Kasi Program dan Advokasi Sosial.

C. Landasan hukum atau peraturan gubernur (PERGUB) yang teratur, karena di peraturan gubernur sendiri sudah tertera tugas dan fungsi dalam kegiatan pelayanan rehabilitasi sosial yang ada di Panti Sosial Bina Serumpun Provinsi Kepualauan Bangka Belitung. Sehingga para petugas yang ada di panti memahami tugas dan fungsi mereka ketika dalam proses pelayanan rehabilitasi sosial.

\section{5 | Penutup}

Pelaksanaan layanan Bimbingan dan Konseling terhadap anak terlantar di
Panti Sosial Bina Serumpun Provinsi Kepulauan Bangka Belitung yang mengacu pada tahap proses pelayanan rehabilitasi sosial dapat dikatakan sudah cukup baik dan diharapkan dapat dipertahankan kalau bisa lebih ditingkatkan lagi. Sedangkan pada pelaksanaan bimbingan keterampilan terhadap anak terlantar dan lansia terlantar sudah baik, namun diharapkan dapat lebih baik lagi dari sebelumnya.

Diharapkan semua proses bimbingan dan konseling yang diberikan oleh pihak panti kepada anak terlantar selalu diterapkan secara baik. Begitu juga pada proses tindak lanjut dapat dikatakan sudah cukup baik, akan tetapi perlu ditingkatkan lagi supaya tujuan yang diinginkan sesuai harapan bersama. Jadi, secara keseluruhan proses pelayanan bimbingan dan konseling terhadap orang terlantar (lansia) dan anak terlantar oleh Panti Sosial Bina Serumpun Provinsi Kepulauan Bangka Belitung sudah dikatakan cukup baik. 


\section{Daftar Pustaka}

[1] Jimmy Hassoloan,dkk, Pancasila dan Kewarganegaraan, Yogyakarta:CVBUDI UTAMA $2019: 38$.

[2] Mohammad Agung Ridlo, Mengupas Problema Kota Semarang Metropolitan, Yogyakarta :CV BUDIUTAMA 2026: 39.

[3] Albian, Kasi Bimbingan UPTD PSBS Provinsi Babel, Wawancara, UPTD PSBS Dinas Sosial Provinsi Kepulauan Bangka Belitung, 04 Maret 2020.

[4] Lexy J.Meleong, Metodologi Penelitian Kualitatif , Bandung: PT. Remaja Rosdakarya, 2005:3

[5] Zulkifli, Metodologi Penelitian Suatu Pengantar, Sungailiat Bangka: Shiddiq Press $2007: 113$

[6] Deddy Mulyana, Metodologi Penelitian Kualitatif, Bandung: PT. Remaja Rosdakarya 2006:18

[7] W.Gulo, Metodologi Penelitian, Jakarta:PT.Grasindo 2007: 11

[8] MelkisedekN.B.C.Neolaka,M.Si, Pendidikan Dasar di Daerah Perbatasan Potret dan Upaya Peningkatan Kualitasnya, (Malang : PT. Cita Intrans Selaras, 2020),hlm. 30

[9] Kamus Besar Bahasa Indonesia (KBBI).

[10] Hermien Nugraheni dkk, Kesehatan Masyarakat Dalam Determinan Sosial Budaya, (Yogyakarta: CV Budi Utama, 2018), hlm. 106. 